\title{
Organic Soil Amendment and Tillage Affect Soil Quality and Plant Performance in Simulated Residential Landscapes
}

\author{
Shawna Loper ${ }^{1}$, Amy L. Shober ${ }^{2,5}$, Christine Wiese ${ }^{3}$, \\ Geoffrey C. Denny ${ }^{2}$, and Craig D. Stanley ${ }^{4}$ \\ University of Florida, IFAS, Gulf Coast Research and Education Center, \\ 14625 CR 672, Wimauma, FL 33598
}

Edward F. Gilman ${ }^{4}$

University of Florida, IFAS, Environmental Horticulture Department, 100 Mehrhof Hall, P.O. Box 110675, Gainesville, FL 32611

Additional index words. compost, woody ornamentals, fertilization

\begin{abstract}
The urban soil environment is usually not conducive to healthy root growth and function, leading to problems with plant establishment, growth, and aesthetic quality. The objective of this study was to determine if the addition of compost with or without the application of shallow tillage or aeration will improve soil physical and chemical properties and plant growth compared with an unamended control in simulated new residential landscapes. Twenty-four mixed landscape plots were established in a randomized complete block design to simulate new residential landscapes. Each plot was constructed using $10 \mathrm{~cm}$ of subsoil fill material over a compacted field soil and planted with Stenotaphrum secundatum and mixed ornamental plant species. Composted dairy manure solids were applied as an organic soil amendment at a depth of $5 \mathrm{~cm} \quad \approx 256$ $\mathrm{Mg} \cdot \mathrm{ha}^{-1}$ ) in combination with two mechanical soil treatments (tillage to $15 \mathrm{~cm}$ and plug aeration) for a total of five soil management treatments plus an untreated control. Soil physical and chemical properties, plant growth, and quality and plant tissue nutrient concentrations were assessed periodically to determine the effect of soil treatment on soil and plant quality. Applications of compost to soils significantly reduced soil bulk density and $\mathrm{pH}$ and increased soil organic matter, electrical conductivity, and Mehlich-1 phosphorus and potassium concentrations. All ornamental plant species, with the exception of Raphiolepis indica (L.) Lindl. ex Ker Gawl., exhibited more growth when grown in soils amended with composted dairy manure solids. In most instances, plant tissue nitrogen and phosphorus concentrations were higher for plants grown in soils receiving compost. Results of our study suggested that the addition of composted dairy manure solids to soils can improve soil properties and enhance plant growth in residential landscapes when sandy fill soils are used. In contrast, shallow tillage and aeration had little effect on soil properties or plant growth.
\end{abstract}

In recent years, many areas of the United States have experienced rapid population growth and urbanization. When land is urbanized, natural ecosystems are replaced by roads, homes, and commercial structures (Wickham

Received for publication 20 May 2010. Accepted for publication 19 July 2010.

This work was supported by the Florida Agricultural Experiment Station, the Florida Department of Agriculture and Consumer Services, the Florida Nursery, Growers and Landscape Association, and the University of Florida Program for Resource Efficient Communities.

We thank Gitta Shurberg, Stew Whitney, and the GCREC field crew for their help collecting and processing samples.

${ }^{1}$ Graduate Research Assistant.

${ }^{2}$ Assistant Professor.

${ }^{3}$ Research and Extension Assistant.

${ }^{4}$ Professor.

${ }^{5}$ To whom reprint requests should be addressed; e-mail alshober@ufl.edu. to improve soil function by increasing waterholding capacity, porosity, and surface area (Cogger, 2005; Zhang, 1994). Organic amendments can help to stabilize soil structure (Thomas et al., 1996) and decrease soil bulk density $\left(D_{\mathrm{b}}\right)$ (Curtis and Claassen, 2009), thereby providing an environment that will allow for the growth of healthy root systems. The use of organic amendments during establishment of Poa pratensis L. has been shown to enhance turf growth and quality (Landschoot and McNitt, 1994; Linde and Hepner, 2005). Organic amendments also supply nutrients to growing plants and increase the concentrations of plant-available nutrients in soils. For example, Ingelmo et al. (1998) reported an increase in soil mineral nitrogen $(\mathrm{N})$ concentration in field soils amended with sewage sludge or municipal solids waste compost (467 and 251 $\mathrm{mg} \cdot \mathrm{kg}^{-1}$, respectively) compared with an unamended soil $\left(79 \mathrm{mg} \cdot \mathrm{kg}^{-1}\right)$. Johnson et al. (2006) reported an increase in soil phosphorus (P) and potassium $(\mathrm{K})$ concentrations as compost application rate increased when dairy cattle manure compost was applied at rates of $0,33,66$, and $99 \mathrm{~m}^{3} \cdot \mathrm{ha}^{-1}$. Similarly, Landschoot and McNitt (1994) showed that incorporation of various composts (e.g., biosolids, brewery byproducts, chicken manure, yard waste, horse/cow manure, papermill byproducts, mushroom substrate) into soils resulted in an increase in available P from $50.4 \mathrm{~kg} \cdot \mathrm{ha}^{-1}$ initially to 93 to $1708 \mathrm{~kg} \cdot \mathrm{ha}^{-1}$ depending on compost type.

The addition of organic amendments can also affect other soil chemical properties, such as $\mathrm{pH}$ and electrical conductivity (EC). Soil EC tends to be higher in compost-amended soils, but the effect of compost on soil $\mathrm{pH}$ (raising or lowering $\mathrm{pH}$ ) is dependent on the chemical properties of the soil and the compost material itself. Calcium carbonates found in manures have been shown to increase $\mathrm{pH}$ when applied to slightly acid to near neutral soils (Eghball, 1999; Weindorf et al., 2006). Ginting et al. (2003) reported that the $\mathrm{pH}$ and EC of soils amended with beef cattle manure or composted feedlot manure (mean $\mathrm{pH}=6.5, \mathrm{EC}=0.49$ $\mathrm{dS} \cdot \mathrm{m}^{-1}$ ) were consistently higher than soils fertilized with inorganic fertilizers or unamended soils (mean $\mathrm{pH}=6.2, \mathrm{EC}=0.34$ $\mathrm{dS} \cdot \mathrm{m}^{-1}$ ). However, other studies have shown no change in soil pH (Foshee et al., 1999) or a decrease in soil $\mathrm{pH}$ (Himelick and Watson, 1990; Scharenbroch, 2009; Wright et al., 2007) after addition of organic amendments (including composts and mulches) compared with unamended soils. Wright et al. (2007) also noted that compost added to the soil provided a buffering effect to $\mathrm{pH}$ increases that were observed in the control as a result of irrigation water source.

Tillage can be used to improve the physical properties of compacted soils. In compacted soils, tillage breaks up massive structure, thereby increasing soil pore space and allowing water to infiltrate and roots to penetrate through the soil profile (Lipiec and Stepniewski, 1995). da Silva et al. (1997) reported that relative $D_{\mathrm{b}}$, which is the ratio of the $D_{\mathrm{b}}$ of a soil to the $D_{\mathrm{b}}$ under standard compaction treatment (i.e., 
samples compacted with $200 \mathrm{kPa}$ of pressure), was lower in soils receiving conventional tillage $\left(0.79 \mathrm{~g} \cdot \mathrm{cm}^{-3}\right)$ when compared with no-till soils $\left(0.87 \mathrm{~g} \cdot \mathrm{cm}^{-3}\right)$. Studies have also shown that surface compaction can be alleviated by spike and core aeration or rototilling (Jim, 1993; Kozlowski, 1999; Unger and Kaspar, 1994), although the benefits of these treatments may be short-lived (Bishop and Grimes, 1978; Murphy et al., 1993). Deep tillage (to $\approx 0.2$ to $0.4 \mathrm{~m}$ ) promotes root growth into subsoil horizons that have more soil structural development and higher soil water-holding capacity than surface soils (Adeoye and Mohamedsaleem, 1990; Akinci et al., 2004; Busscher et al., 2006). However, Bulmer et al. (2007) reported that the benefits of deep tillage alone were temporary. When tillage to a depth of $0.75 \mathrm{~m}$ was applied to a field plot for growth of Pinus contorta Dougl., soil mechanical resistance was in excess of $2500 \mathrm{kPa}$ after 1 year. However, the sandy loam soil had significantly lower soil mechanical resistance after 1 year when composted wood waste was applied in addition to tillage (Bulmer et al., 2007). Additionally, Sommerfeldt and Chang (1985) noted that there were no differences in soil $D_{\mathrm{b}}$ when compost (cattle feedlot manure) was incorporated into clay loam field soil by plow, rototiller, or cultivator.

Although research has shown that soil management practices such as organic amendment additions or tillage can improve the physical and chemical properties of soil, much of the research has been conducted in agricultural systems (Martens and Frankenberger, 1992; Roy et al., 2010) or with trees (Rivenshield and Bassuk, 2007; Scharenbroch, 2009). It is not known if these management practices can significantly improve soil conditions in urban settings, specifically new residential areas, where disturbance of the soil may contribute to environmental degradation and result in poor landscape plant growth. The objective of this study was to determine if the addition of compost with or without the application of shallow tillage or aeration will improve soil physical and chemical properties and plant growth compared with an unamended control in simulated new residential landscapes.

\section{Materials and Methods}

Experimental design. Twenty-four mixed landscape plots $(3.05 \mathrm{~m} \times 3.66 \mathrm{~m})$ were established in a randomized complete block design at the University of Florida-Institute of Food and Agricultural Sciences (IFAS) Gulf Coast Research and Education Center in Wimauma, FL, to simulate new residential landscapes. All vegetation was removed from the site before plot construction. The entire research area was prepared at a $2 \%$ grade (as is typically required by construction codes) and compacted $\left(D_{\mathrm{b}}\right.$ range: 1.7 to $\left.1.9 \mathrm{~g} \cdot \mathrm{cm}^{-3}\right)$ using a small plate compactor (Wacker Neuson, Munich, Germany). Individual landscape plots were constructed inside water-sealed treated wooden boxes. Within each plot, the compacted field soil (Zolfo fine sand; sandy, siliceous, hyperthermic Oxyaquic Alorthods)
(USDA-NRCS, 2004) was then buried under $1.13 \mathrm{~m}^{3}$ of uncompacted soil fill material. Three fill materials were mixed in equal parts to simulate a "top soil" material that would be applied during residential construction. The three fill soil material sources included: a subsoil fill containing construction material and other debris; a clean topsoil material (St. Johns fine sand; sandy, siliceous, hyperthermic Typic Alaquod) obtained from depth of 30 to $60 \mathrm{~cm}$ (Hills Dirt Pit, LLC., Riverview, FL), and a clean subsoil fill (St. Johns fine sand) fill obtained from a depth of 122 to $213 \mathrm{~cm}$ (Hills Dirt Pit, LLC.).

Composted dairy manure solids (compost; Agrigy, Palm Harbor, FL) were applied as an organic soil amendment at a rate of $508 \mathrm{~m}^{3} \cdot \mathrm{ha}^{-1}$ (5-cm depth, equaling $\left.\approx 256 \mathrm{Mg} \cdot \mathrm{ha}^{-1}\right)$ in combination with two mechanical soil treatments (shallow tillage and aeration) for a total of five soil management treatments: 1) tillage only; 2) compost only; 3 ) compost + tillage; 4) aeration only; and 5) compost + aeration. Chemical analysis of the compost indicated that the material had a $\mathrm{pH}$ of 6.59 , an EC of $1.02 \mathrm{dS} \cdot \mathrm{m}^{-1}$, and a total carbon to $\mathrm{N}(\mathrm{C}: \mathrm{N})$ ratio of 13.6. Plots that received compost applications received total $\mathrm{N}$ and EPA 3050 digestible $\mathrm{P}$ at a rate of $\approx 3277$ and $1385 \mathrm{~kg} \cdot \mathrm{ha}^{-1}$, respectively. In plots receiving the tillage treatment, soil (or soil + compost) was turned to a depth of 10 to $15 \mathrm{~cm}$ using a counterrotating tines tiller (Sears Brands, LLC, Hoffman Estates, IL). In plots receiving the aeration treatment, soil aeration plugs were mechanically removed using a core aerator (Billy Goat Industries, Inc., Lee's Summit, MO). An untreated control plot (no tillage or organic amendment) was included as the sixth soil treatment.

Once soil treatments were applied, each plot was split across the contour and $5.58 \mathrm{~m}^{2}$ of the plot was planted with Stenotaphrum secundatum (Walter) Kuntze turfgrass; the remaining $5.58 \mathrm{~m}^{2}$ was planted with ornamental plants. Ornamental plants species, selected to represent species commonly installed in Florida urban landscapes, included: Galphimia glauca Cav., Rhaphiolepis indica (L.) Lindl. ex Ker Gawl., Ilex cornuta 'Burfordi' Lindl. \& Paxton, and Liriope muscari (Decne.) L. H. Bailey. In all landscape plots, turfgrass was fertilized at a total $\mathrm{N}$ rate of $220 \mathrm{~kg} \cdot \mathrm{ha}^{-1}$ based on current University of Florida-IFAS recommendations for South Florida (moderate maintenance) (Sartain, 2007): complete turf fertilizer (26N-0.9P-9.1K; Lesco Professional Turf Fertilizer, Sebring, FL) at an N rate of $48.8 \mathrm{~kg} \cdot \mathrm{ha}^{-1}$ per application in February and October, polymer-coated urea $(42 \mathrm{~N}-0.0 \mathrm{P}-$ $0.0 \mathrm{~K}$; Harrell's Professional Fertilizer Solutions, Lakeland, FL) as a slow-release N source at and $\mathrm{N}$ rate of $48.8 \mathrm{~kg} \cdot \mathrm{ha}^{-1}$ per application in May and August, urea (46N-0.0P-0.0K; Potash Corp., Northbrook, IL) as a soluble N source at an N rate of $24.4 \mathrm{~kg} \cdot \mathrm{ha}^{-1}$ in April, and $6.34 \mathrm{~L} \cdot \mathrm{ha}^{-1}$ of ferrous sulfate (Sunniland Corporation, Sanford, FL) in July. Ornamental plants were fertilized every 3 months with urea $(40 \mathrm{~N}-0.0 \mathrm{P}-0.0 \mathrm{~K})$ at an $\mathrm{N}$ rate of $24.4 \mathrm{~kg} \cdot \mathrm{ha}^{-1}$ per application based on University of FloridaIFAS recommendations for established woody ornamentals grown in the landscape (Knox et al., 2002). The nutrient content of added compost was not considered when fertilizing turfgrass or ornamentals because compost was applied based on horticultural recommendations to improve soil conditions (Urban, 2008) rather than as a nutrient source.

The entire research plot area was equipped with a spray irrigation system, which allowed for individual landscape plots to be irrigated, as needed, based on University of FloridaIFAS recommendations (Zazueta et al., 2005). Plots were watered daily for $30 \mathrm{~d}$ after planting to allow for establishment of turf and ornamental plant material. Irrigation frequency was then reduced to $2 \mathrm{~d}$ per week based on typical watering restrictions for landscape irrigation that would be mandated in times of drought (South Florida Water Management District, 2010; St. Johns River Water Management District, 2010). Irrigation was applied for $51 \mathrm{~min}$ (irrigation controller run time for two irrigation events per week at a 0.13 $\mathrm{cm} \cdot \mathrm{h}^{-1}$ application rate, assuming system efficiency of $80 \%$ and considering effective rainfall) per plot on Mondays and Thursdays starting at $0300 \mathrm{HR}$ and ending at $\approx 0900 \mathrm{HR}$.

Soil physical and chemical properties. Soil physical and chemical properties were measured before tillage, aeration, and compost treatments were applied and then repeated every 3 months $[0,13,27,40$, and 52 weeks after treatment (WAT)] for a period of 1 year. Soil $D_{\mathrm{b}}$ was measured on a single soil core collected from the turf and ornamental beds (two samples per plot) at 0 to $10 \mathrm{~cm}$ using the core method (Blake and Hartge, 1986). Ten to 15 soil cores were collected in a random pattern from the turf areas and ornamentals beds in each landscape plot using a soil probe at a depth of 0 to $10 \mathrm{~cm}$ and 10 to $20 \mathrm{~cm}$ and mixed together to form two composite samples per plot (one per depth). Composite soil samples were then air-dried at room temperature $\left(25 \pm 2{ }^{\circ} \mathrm{C}\right)$ and sieved to pass a $2-\mathrm{mm}$ screen. Soil pH (1:2 soil to deionized water ratio), EC (1:2 soil to deionized water ratio), and $\mathrm{OM}$ (loss on ignition) were determined by standard methods of the University of FloridaIFAS Extension Soil Testing Laboratory (Mylavarapu, 2009). Soil moisture content at field capacity was determined by the method described in Tan (1996) and particle size was determined by the hydrometer method (Bouyoucos, 1962). Composite soil samples were extracted using the Mehlich-1 solution (1:4 ratio of soil to $0.0125 \mathrm{M} \mathrm{H}_{2} \mathrm{SO}_{4}+0.05 \mathrm{M}$ $\mathrm{HCl}$ ) (Mylavarapu, 2009) and analyzed for $\mathrm{P}$ and $\mathrm{K}$ by inductively coupled plasma atomic emission spectroscopy (ICP-AES).

Plant growth, root growth, and tissue analysis. Plant growth measurements and tissue nutrient content were determined at 13 and 40 WAT to evaluate the effect of soil tillage or compost amendment on the establishment and growth of ornamental plants and turfgrass. Growth index (GI) was used as a quantitative indicator of ornamental plant growth rate and to compare the size of the plants grown in the different soil treatments. GI for each plant was calculated as: $\mathrm{GI}\left(\mathrm{m}^{3}\right)=\mathrm{H} \times \mathrm{W} 1 \times \mathrm{W} 2$; where 
$\mathrm{H}$ is the plant height $(\mathrm{m}), \mathrm{W} 1$ is the widest width $(\mathrm{m})$, and $\mathrm{W} 2$ is the width perpendicular to the widest width $(\mathrm{m})$ (Scheiber et al., 2007). Turfgrass was mowed on an as-needed basis with most mowing events occurring during the summer months. Turf clippings were collected during mowing events at 13 and 40 WAT to determine clipping dry weight based on the method outlined by Ervin and Koski (2001) with some modifications. A 0.46-m wide section from the center of each plot was mowed to a height of $5.7 \mathrm{~cm}$. The clippings were collected from a bag attached to the mower after every plot and then dried to a constant mass at $105^{\circ} \mathrm{C}$ and weighed. Ornamental and turf tissue samples were collected by randomly sampling $\approx 40$ to 50 leaves or blades of grass from each plot at 13 and 40 WAT. Plant tissue samples were dried at $105^{\circ} \mathrm{C}$ and digested using the standard method of the University of Florida-IFAS Extension Soil Testing Laboratory (Mylavarapu, 2009) and analyzed for total Kjeldahl N (TKN), and total $\mathrm{P}$ and $\mathrm{K}$ by ICP-AES.

Shrub root cross-sectional area was used to compare the influence of soil treatments on root growth of shrub species (i.e., G. glauca, $R$. indica, and I. cornuta) based on the methods outlined by Gilman et al. (2010). Shrubs from all landscape plots were dug from the ground and soil was removed from the root balls using a high-pressure water spray. A caliper was used to measure the diameter of the 15 largest roots growing at a soil depth of 0 to $10 \mathrm{~cm}$ that measured greater than $1 \mathrm{~cm}$. The cross-sectional area of each root was then calculated from root diameter as: CSA $\left(\mathrm{cm}^{2}\right)=(1 / 2 \times \text { root diameter })^{2} \times \pi$.

Data analysis. The experiment was designed as a randomized complete block split-plot design with four blocks and six soil treatments (main plot) in each block. Half of each plot was planted with ornamental plants and the other half was planted with turfgrass (subplot) as described previously. The soil treatments were assigned randomly within each block. Soil properties were analyzed using the PROC MIXED procedure in SAS with soil treatment as a fixed effect and block as a random effect (SAS Institute, 2003). Plant cover was added as a fixed effect for analysis of $D_{\mathrm{b}}$ samples, because separate samples were collected from turf and ornamental beds. Plant GI was analyzed separately for each shrub species using the PROC MIXED procedure in SAS with soil treatment as a fixed effect and block as a random effect (SAS Institute, 2003); initial GI (measured at 0 WAT) was included in the model as a covariate to account for variation in initial plant size. Soil and plant GI data were analyzed separately for each sample collection date when significant treatment $x$ date interaction or date effects were noted. Root cross-sectional area was analyzed using the PROC GLM procedure in SAS (SAS Institute, 2003). All data were checked for normality by examining histogram and normality plots of the conditional residuals (generated by the command plots $=$ residual panel). All pairwise comparisons were completed using the Tukey honestly significant difference test with a significance level of $\alpha=0.05$.

\section{Results and Discussion}

Soil physical and chemical properties. Initial soil samples were divided between the topsoil fill $(0$ to $10 \mathrm{~cm})$ and the native field soil $(10$ to $20 \mathrm{~cm})$. Soil particle size analysis indicated that the texture classification of the topsoil fill was loamy sand and the native field soil was sand. The pH was 7.5 and 6.5 and the EC was 0.30 and $0.49 \mathrm{dS} \cdot \mathrm{m}^{-1}$ for the topsoil fill and the field soil, respectively. Initial Mehlich1 nutrient content analysis indicated that the field soil had lower nutrient concentrations, with the exception of $\mathrm{P}$, than the topsoil fill. Mehlich-1 P and K concentrations were 145 and $20.2 \mathrm{mg} \cdot \mathrm{kg}^{-1}$ in the topsoil fill and 77.6 and $9.7 \mathrm{mg} \cdot \mathrm{kg}^{-1}$ in the native field soil. Based on soil test results, only applications of $\mathrm{N}$ and $\mathrm{K}$ would be recommended for these soils (Kidder et al., 1998).

There were no significant changes in soil particle size distribution as a result of soil treatment throughout the study; the soils were predominantly sand (mean $=88 \%$ ) with very little silt $($ mean $=5 \%)$ or clay $($ mean $=6 \%)$ (data not shown). A significant soil treatment $\times$ vegetative cover interaction on soil $D_{\mathrm{b}}$ was evident; soil $D_{\mathrm{b}}$ generally followed the trend: compost-amended soils planted with ornamental plants $<$ compost-amended soils planted with turf $<$ unamended (control) or tilled/ aerated soils planted with turf $\approx$ unamended (control) or tilled/aerated soils planted with ornamental plants (Table 1). Multiple researchers have reported decreased $D_{\mathrm{b}}$ as a result of incorporating compost (derived from materials including yard waste, biosolids, brewery byproducts, chicken manure, horse/ cow manure, papermill byproducts, mushroom substrate) into field soils (Curtis and Claassen, 2009; Landschoot and McNitt, 1994). While we reported a decrease in soil $D_{\mathrm{b}}$, the $D_{\mathrm{b}}$ of the unamended soils was less than the $1.8 \mathrm{~g} \cdot \mathrm{cm}^{-1}$ threshold for root restriction for a sandy soil (Hanks and Lewandowski, 2003), suggesting that $D_{\mathrm{b}}$ was unlikely to influence plant growth in our study. The significant vegetative cover $\times$ soil treatment effect on soil $D_{\mathrm{b}}$ is likely related to physiological differences in the root systems

Table 1. Bulk density $\left(D_{\mathrm{b}}\right)$ of fill soil samples $(n=4)$ collected from 0 - to 10 -cm depth in simulated residential landscape plots receiving compost, shallow tillage, and/or aeration treatments averaged over five sampling dates.

\begin{tabular}{llc}
\hline Treatment & Plant cover & Bulk density $\left(\mathrm{g} \cdot \mathrm{cm}^{-3}\right)$ \\
\hline Control & Ornamental plants & $1.65 \mathrm{a}^{z}$ \\
Tillage only & Ornamental plants & $1.63 \mathrm{ab}$ \\
Aeration only & Ornamental plants & $1.66 \mathrm{a}$ \\
Compost only & Ornamental plants & $1.00 \mathrm{~g}$ \\
Compost + tillage & Ornamental plants & $1.22 \mathrm{ef}$ \\
Compost + aeration & Ornamental plants & $1.09 \mathrm{fg}$ \\
Control & S. Secundatum & $1.52 \mathrm{abc}$ \\
Tillage only & S. Secundatum & $1.58 \mathrm{abc}$ \\
Aeration only & S. Secundatum & $1.50 \mathrm{abc}$ \\
Compost only & S. Secundatum & $1.46 \mathrm{bcd}$ \\
Compost + tillage & S. Secundatum & $1.29 \mathrm{de}$ \\
Compost + aeration & S. Secundatum & $1.43 \mathrm{~cd}$ \\
\hline
\end{tabular}

${ }^{z}$ Values with the same letter are not significantly different at $P<0.05$ using Tukey's honestly significant difference test. of woody ornamentals versus turfgrass (i.e., enhanced growth of woody roots in the compost-amended soils created more macropores, resulting in decreased bulk density. Although turf root growth was probably also enhanced by application of compost, the fibrous nature of the root systems made turf roots less effective at increasing soil porosity and, thereby, decreasing bulk density.

Addition of compost (incorporated or as a top-dress) significantly increased the soil field moisture capacity compared with unamended soils at all sampling dates (Table 2). We found that compost application improved soil field moisture capacity, thereby increasing the volume of plant-available water in the soil. Pandey and Shukla (2006) reported that the application of yard trimming compost to soils at a commercial vegetable farm at a rate of $100 \mathrm{Mg} \cdot \mathrm{ha}^{-1}$ increased the soil moisture content compared with soils to which no compost was applied. Similarly, Curtis and Claassen (2009) found that plant-available water was increased after the addition of composted yard waste to coarsetextured field soils at a rate of $540 \mathrm{Mg} \cdot \mathrm{ha}^{-1}$ (on a dry mass basis; equivalent to $25 \%$ by vol.). However, the authors noted that there was no difference in plant-available water between fine-textured field soils amended with compost and unamended soils.

As expected, the application of compost increased the soil OM content compared with unamended soils through 40 WAT (Table 2). These results are consistent with many other studies that report increases in soil OM after the addition of compost materials (Curtis and Claassen, 2009; Ingelmo et al., 1998; Landschoot and McNitt, 1994; Wright et al., 2007). Manures and manure-based compost typically contain lower amounts of lignin and higher amounts of cellulose (and other more labile $\mathrm{C}$ forms) than composts derived from woody plant materials (Casale et al., 1995; Litvany and Ozores-Hampton, 2002), suggesting that $\mathrm{C}$ in these composted manures would be a readily available energy source for soil microbes. Therefore, we hypothesize that the low lignin content of the composted dairy manure solids used in our study, coupled with the warm, wet conditions that are common in Florida, allowed for rapid oxidation of $\mathrm{C}$ after woody versus fibrous). We hypothesize that 
Table 2. Selected physical and chemical properties of fill soil samples $(\mathrm{n}=4)$ collected from 0 - to 10 -cm depth in simulated residential landscape plots receiving compost, shallow tillage, and/or aeration treatments at five sampling dates.

\begin{tabular}{|c|c|c|c|c|c|}
\hline Treatment & $0 \mathrm{WAT}^{\mathrm{z}}$ & $13 \mathrm{WAT}$ & 27 WAT & $40 \mathrm{WAT}$ & $52 \mathrm{WAT}$ \\
\hline \multicolumn{6}{|c|}{ Field capacity $\left(\mathrm{g} \cdot \mathrm{kg}^{-1}\right)$} \\
\hline Control & $105 b^{y}$ & $123 \mathrm{~b}$ & $123 \mathrm{~cd}$ & $126 \mathrm{~cd}$ & $128 \mathrm{c}$ \\
\hline Tillage only & $101 \mathrm{c}$ & $120 \mathrm{~b}$ & $119 \mathrm{~cd}$ & $121 \mathrm{~cd}$ & $126 \mathrm{c}$ \\
\hline Aeration only & $101 \mathrm{c}$ & $123 \mathrm{~b}$ & $107 \mathrm{~d}$ & $111 \mathrm{~d}$ & $118 \mathrm{c}$ \\
\hline Compost only & $213 \mathrm{a}$ & $199 \mathrm{a}$ & $145 \mathrm{~b}$ & $153 \mathrm{ab}$ & $159 \mathrm{~b}$ \\
\hline Compost + tillage & $175 \mathrm{a}$ & $199 \mathrm{a}$ & $168 \mathrm{a}$ & $172 \mathrm{a}$ & $190 \mathrm{a}$ \\
\hline Compost + aeration & $162 \mathrm{ab}$ & $199 \mathrm{a}$ & $137 \mathrm{bc}$ & $139 \mathrm{bc}$ & $155 \mathrm{~b}$ \\
\hline \multicolumn{6}{|c|}{ Organic matter $\left(\mathrm{g} \cdot \mathrm{kg}^{-1}\right)$} \\
\hline Control & $16.5 \mathrm{~b}$ & $23.1 \mathrm{~b}$ & $15.0 \mathrm{ab}$ & $7.00 \mathrm{c}$ & $26.1 \mathrm{a}$ \\
\hline Tillage only & $19.0 \mathrm{~b}$ & $28.6 \mathrm{~b}$ & $8.50 \mathrm{~b}$ & $10.5 \mathrm{c}$ & $17.5 \mathrm{a}$ \\
\hline Aeration only & $17.5 \mathrm{~b}$ & $28.7 \mathrm{~b}$ & $10.0 \mathrm{~b}$ & $13.5 \mathrm{bc}$ & $18.4 \mathrm{a}$ \\
\hline Compost only & $46.3 \mathrm{a}$ & $63.1 \mathrm{a}$ & $31.7 \mathrm{ab}$ & $32.6 \mathrm{ab}$ & $30.3 \mathrm{a}$ \\
\hline Compost + tillage & $54.4 \mathrm{a}$ & $60.9 \mathrm{a}$ & $37.6 \mathrm{a}$ & $46.3 \mathrm{a}$ & $32.0 \mathrm{a}$ \\
\hline Compost + aeration & $44.8 \mathrm{a}$ & $60.9 \mathrm{a}$ & $33.0 \mathrm{ab}$ & $33.1 \mathrm{ab}$ & $31.4 \mathrm{a}$ \\
\hline \multicolumn{6}{|c|}{$p H$} \\
\hline Control & $7.46 \mathrm{a}$ & $7.63 \mathrm{a}$ & $7.73 \mathrm{a}$ & $7.66 \mathrm{a}$ & $7.87 \mathrm{ab}$ \\
\hline Tillage only & $7.37 \mathrm{a}$ & $7.59 \mathrm{ab}$ & $7.76 \mathrm{a}$ & $7.71 \mathrm{a}$ & $7.98 \mathrm{a}$ \\
\hline Aeration only & $7.48 \mathrm{a}$ & $7.69 \mathrm{a}$ & $7.86 \mathrm{a}$ & $7.76 \mathrm{a}$ & $7.93 \mathrm{ab}$ \\
\hline Compost only & $7.32 \mathrm{a}$ & $7.20 \mathrm{c}$ & $7.11 \mathrm{~b}$ & $7.09 \mathrm{~b}$ & $7.39 \mathrm{c}$ \\
\hline Compost + tillage & $7.36 \mathrm{a}$ & $7.36 \mathrm{abc}$ & $7.35 \mathrm{~b}$ & $7.32 \mathrm{~b}$ & $7.65 \mathrm{bc}$ \\
\hline Compost + aeration & $7.35 \mathrm{a}$ & $7.22 \mathrm{bc}$ & $7.16 \mathrm{~b}$ & $7.13 \mathrm{~b}$ & $7.43 \mathrm{c}$ \\
\hline \multicolumn{6}{|c|}{ Electrical conductivity $\left(d S \cdot m^{-1}\right)$} \\
\hline Control & $0.30 \mathrm{~b}$ & $0.30 \mathrm{bc}$ & $0.13 \mathrm{bcd}$ & $0.40 \mathrm{a}$ & $0.22 \mathrm{a}$ \\
\hline Tillage only & $0.32 \mathrm{~b}$ & $0.29 \mathrm{bc}$ & $0.10 \mathrm{~d}$ & $0.31 \mathrm{a}$ & $0.35 \mathrm{a}$ \\
\hline Aeration only & $0.31 \mathrm{~b}$ & $0.25 \mathrm{c}$ & $0.13 \mathrm{~cd}$ & $0.22 \mathrm{a}$ & $0.41 \mathrm{a}$ \\
\hline Compost only & $0.58 \mathrm{ab}$ & $0.39 \mathrm{a}$ & $0.18 \mathrm{ab}$ & $0.50 \mathrm{a}$ & $0.29 \mathrm{a}$ \\
\hline Compost + tillage & $0.63 \mathrm{a}$ & $0.40 \mathrm{ab}$ & $0.16 \mathrm{abc}$ & $0.42 \mathrm{a}$ & $0.38 \mathrm{a}$ \\
\hline Compost + aeration & $0.59 \mathrm{ab}$ & $0.35 \mathrm{a}$ & $0.20 \mathrm{a}$ & $0.27 \mathrm{a}$ & $0.41 \mathrm{a}$ \\
\hline \multicolumn{6}{|c|}{ Phosphorus $\left(\mathrm{mg} \cdot \mathrm{kg}^{-1}\right)$} \\
\hline Control & $141 \mathrm{ab}^{\mathrm{y}}$ & $127 \mathrm{c}$ & $146 \mathrm{c}$ & $166 \mathrm{bc}$ & $154 \mathrm{bc}$ \\
\hline Tillage only & $157 \mathrm{ab}$ & $150 \mathrm{bc}$ & $167 \mathrm{bc}$ & $180 \mathrm{abc}$ & $167 \mathrm{abc}$ \\
\hline Aeration only & $130 \mathrm{~b}$ & $135 \mathrm{c}$ & $172 \mathrm{bc}$ & $147 \mathrm{c}$ & $122 \mathrm{c}$ \\
\hline Compost only & $181 \mathrm{a}$ & $200 \mathrm{a}$ & $219 \mathrm{a}$ & $216 \mathrm{ab}$ & $214 \mathrm{a}$ \\
\hline Compost + tillage & $184 \mathrm{a}$ & $191 \mathrm{ab}$ & $219 \mathrm{a}$ & $217 \mathrm{a}$ & $193 \mathrm{ab}$ \\
\hline Compost + aeration & $171 \mathrm{ab}$ & $208 \mathrm{a}$ & $193 \mathrm{ab}$ & $226 \mathrm{a}$ & $212 \mathrm{a}$ \\
\hline \multicolumn{6}{|c|}{ Potassium $\left(\mathrm{mg} \cdot \mathrm{kg}^{-1}\right)$} \\
\hline Control & $23.3 \mathrm{c}$ & $27.8 \mathrm{~b}$ & $19.8 \mathrm{~b}$ & $23.5 \mathrm{a}$ & $24.0 \mathrm{a}$ \\
\hline Tillage only & $29.3 \mathrm{c}$ & $35.3 \mathrm{~b}$ & $23.8 \mathrm{ab}$ & $35.3 \mathrm{a}$ & $24.5 \mathrm{a}$ \\
\hline Aeration only & $86.5 \mathrm{bc}$ & $32.5 \mathrm{~b}$ & $21.3 \mathrm{~b}$ & $27.5 \mathrm{a}$ & $27.0 \mathrm{a}$ \\
\hline Compost only & $212 \mathrm{ab}$ & $64.3 \mathrm{a}$ & $29.8 \mathrm{ab}$ & $39.0 \mathrm{a}$ & $25.0 \mathrm{a}$ \\
\hline Compost + tillage & $268 \mathrm{a}$ & $61.0 \mathrm{a}$ & $37.3 \mathrm{a}$ & $38.3 \mathrm{a}$ & $29.5 \mathrm{a}$ \\
\hline Compost + aeration & $233 \mathrm{ab}$ & $55.8 \mathrm{a}$ & $39.5 \mathrm{a}$ & $37.8 \mathrm{a}$ & $29.8 \mathrm{a}$ \\
\hline
\end{tabular}

${ }^{\mathrm{z}} \mathrm{WAT}=$ weeks after treatment.

${ }^{\mathrm{y}}$ Values within the same sampling date (WAT) with the same letter are not significantly different at $P<$ 0.05 using Tukey's honestly significant difference test.

the compost was applied to the soil. As a result, we reported no treatment differences on soil OM content after 40 WAT (Table 2).

The soil $\mathrm{pH}$ and EC were affected by the application of compost and, in some cases, tillage treatments. Soils that received compost additions had a lower soil $\mathrm{pH}$ (mean $\mathrm{pH}=$ 7.29) than unamended soils $(\mathrm{pH}=7.70)$; this trend persisted from 13 through 52 WAT (Table 2). The decrease in soil $\mathrm{pH}$ after application of compost was the result of the addition of compost with a lower $\mathrm{pH}$ than reported in the fill soils (compost $\mathrm{pH}=6.59$; fill soil $\mathrm{pH}=7.50$ ) or the production of $\mathrm{H}_{2} \mathrm{CO}_{3}$ during microbial oxidation of compost derived C (Scharenbroch, 2009). Other researchers have documented that the $\mathrm{pH}$ of compost can influence soil $\mathrm{pH}$ when compost is applied to the soil (Eghball, 1999, 2002; Scharenbroch, 2009; Weindorf et al., 2006). The decrease in $\mathrm{pH}$ after addition of compost to our soils may a higher EC $\left(1.02 \mathrm{dS} \cdot \mathrm{m}^{-1}\right)$ than the fill soil $\left(0.30 \mathrm{dS} \cdot \mathrm{m}^{-1}\right)$. However, the application of this compost did not increase soil EC to levels (greater than $3 \mathrm{dS} \cdot \mathrm{m}^{-3}$ ) that would be detrimental to even the most salt-sensitive landscape plants (Miyamoto et al., 2004). After 27 WAT, compost-amended soils no longer had higher EC than the soils receiving no compost, which was probably a result of the added salts leaching downward through the soil profile with heavy rain events. Additionally, Mehlich-1 sodium ( $\mathrm{Na}$ ) concentrations in the compost-amended soils decreased from $66.9 \mathrm{mg} \cdot \mathrm{kg}^{-1}$ at $0 \mathrm{WAT}$ to $23.6 \mathrm{mg} \cdot \mathrm{kg}^{-1}$ (not significantly different from unamended soils) by 13 WAT. These soil test Na concentrations were below values that would impact plant growth (E.A. Hanlon, personal communication).

The nutrient content of soil was also affected by the addition of compost. Concentrations of Mehlich-1 P were generally higher in composted soils (Table 2); however, all soils in our study had very high Mehlich-1 P concentrations and would require no additional P fertilizer (Kidder et al., 1998). Wright et al. (2007) reported an increase in $\mathrm{NH}_{4} \mathrm{OAc}$ EDTA-extractable $\mathrm{P}$ in soils with increasing compost application rates. Gilley and Eghball (2002) also found that soil test (Bray 1) P at 0 to 5 and 5 to $15 \mathrm{~cm}$ was significantly greater after 4 years of corn production when composted beef manure was applied based on crop N requirements. Warman et al. (2009) found that an application of municipal solid waste compost applied to field soil at an $\mathrm{N}$ rate of $400 \mathrm{~kg} \cdot \mathrm{ha}^{-1}$ resulted in greater Mehlich-3extractable $\mathrm{P}$ and $\mathrm{K}$ compared with an unamended field soil. Similarly, we also showed an increase in the concentration of Mehlich-1 $\mathrm{K}$ concentrations when compost was applied (Table 2). Mehlich-1 soil test interpretations for Florida indicated that the soil test $\mathrm{K}$ in the compost amended soils was high (61 to 125 $\mathrm{mg} \cdot \mathrm{kg}^{-1}$; no fertilizer recommended) (Kidder et al., 1998) through 13 WAT as a result of high $\mathrm{K}$ content in the compost. As a result, Mehlich-1 K concentrations were sufficient for growth of turf and ornamental plants throughout much of the study (Kidder et al., 1998). However, Mehlich-1 K concentrations in compost-amended soils had declined by 52 WAT, suggesting that $\mathrm{K}$ was absorbed by plant roots or leached downward into the soil profile (Table 2).

Plant growth, root growth, and tissue analysis. The response of plants to the application of compost was species-dependent. Although compost and tillage treatments had no effect on plant GI at 13 WAT (Table 3), one or more of the soil treatments that included compost increased the GI of G. glauca, I. cornuta, and L. musicari by 40 WAT (Table $3)$. The application of compost also increased root growth of G. glauca and I. cornuta. Mean total cross-sectional area of G. glauca roots was 578,681 , and $809 \mathrm{~cm}^{2}$ in composted soils (compost only, compost + aeration, and compost + tillage, respectively) compared with 206 $\mathrm{cm}^{2}$ in the unamended control soil. Similarly, total cross-sectional area of I. cornuta roots 
was 706,597 , and $578 \mathrm{~cm}^{2}$ in composted soils (compost only, compost + aeration, and compost + tillage, respectively), compared with $339 \mathrm{~cm}^{2}$ in the unamended soils. In contrast, soil treatments did not affect the GI (Table 3) or root growth (data not shown) of $R$. indica. In general, soils amended with composted dairy manure solids resulted in larger plants than unamended soils. Shoot and root growth differences between species were attributed to differences in plant growth habits and nutritional needs. The dry mass of $S$. secundatum clippings was greater from compost-amended soils compared with uncomposted soils at 13 WAT (Table 4). Although there were no significant soil treatment effects at 40 WAT, our results suggest that adding compost may help turf to establish more quickly and produce greater biomass compared with unamended soils (Table 4).

Several researchers have reported an increase in shoot and root growth of ornamental landscape plants or turf after the application of composts. For example, a study by Rivenshield (2003) found that additions of food waste compost to compacted urban soil increased plant vigor and growth of Acer saccharum Marshall and Acer saccharinum L. trees. Curtis and Claassen (2009) reported an increase in biomass of ornamental grasses [10.8 times greater for Elymus multisetus (J. G. Sm.) Burtt Davy and 1.6 times greater for Nassella pulchra (Hitchc.) Barkworth] compared with control or tillage alone treatments when yard waste compost was applied to disturbed soils formed from lahar or sandstone parent material, respectively. Similarly, Caravaca et al. (2003) reported an increase in shoot biomass of $120 \%$ and $360 \%$ for Pistacia lentiscus L. and Retama sphaerocarpa (L.) Boiss. shrubs, respectively, planted into a degraded silt-loam soil amended with composted urban residue. Scharenbroch (2009) also reported an increase in shoot and root growth across plant species and organic amendment types when organic amendments were added to soil.

There are several possible explanations for the improved growth of ornamentals and turf reported in our study. For example, the increase in field capacity (and corresponding increase in plant-available water) may have impacted root and shoot growth. However, because plant water stress was not measured in this study, we cannot definitively say whether an increase in water-holding capacity of the soil was responsible for the increase in plant growth. Alternatively, it is possible that plant growth was enhanced as a result of increased soil fertility attributable to the addition of significant amounts of plant nutrients in the compost (particularly $\mathrm{N}$ that was mineralized as a result of soil microbial activity stimulated by compost application). This theory is supported by our results showing an increase in tissue TKN when plants were grown

Table 3. Growth index $\left(\mathrm{m}^{3}\right)$ and plant tissue nutrient content $\left(\mathrm{g} \cdot \mathrm{kg}^{-1}\right)$ for landscape ornamentals $(\mathrm{n}=8)$ grown in sandy fill soils receiving compost, shallow tillage, and/or aeration treatments in simulated residential landscape plots at 13 and 40 weeks after treatment.

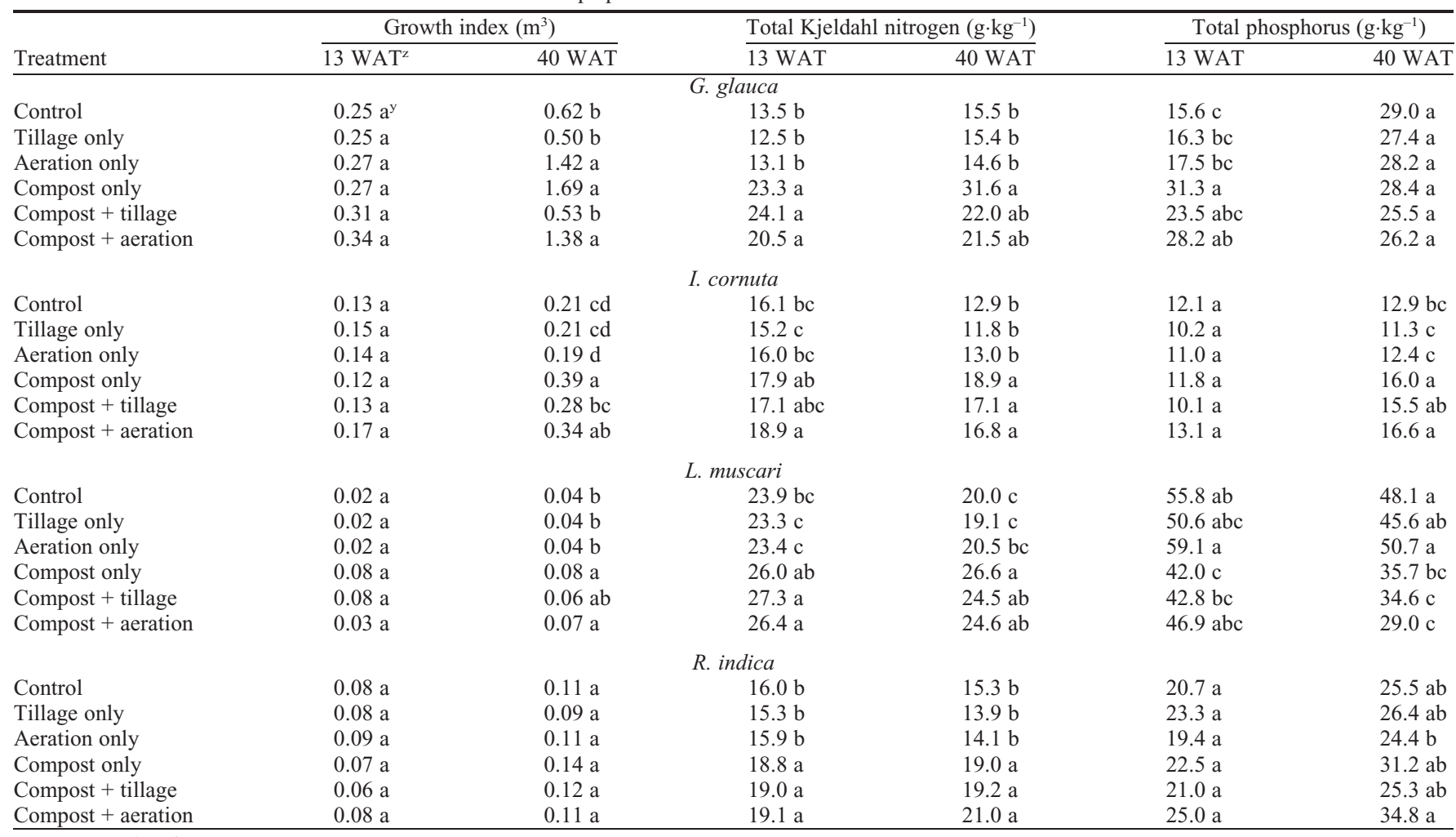

${ }^{\mathrm{z}} \mathrm{WAT}=$ weeks after treatment.

${ }^{y}$ Values within the same sampling date (WAT) with the same letter are not significantly different at $P<0.05$ using Tukey's honestly significant difference test.

Table 4. Dry mass and nutrient concentrations $(\mathrm{n}=4)$ of Stenotaphrum secundatum clippings collected from turf grown in sandy soils receiving compost, shallow tillage, and/or aeration treatments in simulated landscape plots at 13 and 40 WAT.

\begin{tabular}{|c|c|c|c|c|c|c|}
\hline \multirow[b]{2}{*}{ Treatment } & \multicolumn{2}{|c|}{ Dry mass (g) } & \multicolumn{2}{|c|}{ Total Kjedahl nitrogen $\left(\mathrm{g} \cdot \mathrm{kg}^{-1}\right)$} & \multicolumn{2}{|c|}{ Total phosphorus $\left(\mathrm{g} \cdot \mathrm{kg}^{-1}\right)$} \\
\hline & $13 \mathrm{WAT}$ & $40 \mathrm{WAT}$ & $13 \mathrm{WAT}$ & $40 \mathrm{WAT}$ & $13 \mathrm{WAT}$ & $40 \mathrm{WAT}$ \\
\hline Tillage only & $14.5 \mathrm{~b}$ & $3.97 \mathrm{a}$ & $18.8 \mathrm{~b}$ & $17.2 \mathrm{~b}$ & $44.4 \mathrm{~b}$ & $57.4 \mathrm{a}$ \\
\hline Aeration only & $19.4 \mathrm{~b}$ & $5.37 \mathrm{a}$ & $20.3 \mathrm{~b}$ & $16.8 \mathrm{~b}$ & $47.5 \mathrm{~b}$ & $58.3 \mathrm{a}$ \\
\hline Compost + tillage & $86.6 \mathrm{a}$ & $19.6 \mathrm{a}$ & $28.7 \mathrm{a}$ & $26.1 \mathrm{a}$ & $68.1 \mathrm{a}$ & $39.1 \mathrm{bc}$ \\
\hline Compost + aeration & $70.1 \mathrm{a}$ & $31.8 \mathrm{a}$ & $26.2 \mathrm{a}$ & $28.1 \mathrm{a}$ & $66.6 \mathrm{a}$ & $40.8 \mathrm{bc}$ \\
\hline
\end{tabular}

${ }^{\mathrm{z} W A T}=$ weeks after treatment.

${ }^{y}$ Values within the same sampling date (WAT) with the same letter are not significantly different at $P<0.05$ using Tukey's honestly significant difference test. 
in soils receiving compost (+ inorganic $\mathrm{N}$ ) compared with those grown in unamended soils (inorganic $\mathrm{N}$ only) (Tables 3 and 4 ). The concentration of TKN in the tissue of ornamentals and turf grown in soils receiving composted was higher than for plants grown in uncomposted soils that received only inorganic sources of N (Tables 3 and 4). Based on published concentrations of adequate tissue $\mathrm{N}$ for woody ornamentals (20 to 25 $\mathrm{mg} \cdot \mathrm{kg}^{-1}$ ) (Yeager, 2010) and S. secundatum (20 to $30 \mathrm{mg} \cdot \mathrm{kg}^{-1}$ ) (Sartain, 2008), our results suggest a plant response as a result of the mineralization of compost $\mathrm{N}$ (perhaps resulting from enhanced soil microbial activity).

Although there was a more pronounced effect of compost on tissue P content of $G$. glauca (13 WAT) and I. cornuta (40 WAT) than the other ornamental plant species (Tables 3 and 4), the overall trends indicate that tissue $\mathrm{P}$ concentrations were sufficient for plants grown with or without compost [1.5 to 5.0 $\mathrm{mg} \cdot \mathrm{kg}^{-1}$ for woody ornamentals and $S$. secundatum (Sartain, 2008; Yeager, 2010)]. Soil treatments had little consistent effect on levels of tissue total $\mathrm{K}$ at any time for any shrub species, but tissue levels were above reported sufficiency ranges for all treatments (data not shown). Therefore, a response to $\mathrm{P}$ and $\mathrm{K}$ added in the compost treatments was unlikely.

\section{Conclusions}

Based on results from our study, we suggest that composted dairy manure solids can improve soil physical and chemical properties in residential landscapes when sandy fill soils are used. Application of composted dairy manure solids can also enhance the establishment and improve the growth of selected ornamental landscape plants. However, topdressing with composted dairy manure solids enhanced plant growth and quality as much as incorporation of compost to a depth of $20 \mathrm{~cm}$ by tillage. In contrast, shallow tillage and aeration had little effect on the physical properties (e.g., bulk density, field capacity) of sandy fill soils. Our results may have been different if finer-textured soils had been evaluated, in which the threshold for $D_{\mathrm{b}}$ above which root growth would be compromised is lower. Similarly, there were no significant effects of plug soil aeration on plant establishment or growth, suggesting that the lack of effects from soil physical disturbances (tillage or aeration) was the result of the coarsetextured soils that allowed for adequate root growth at the recorded bulk density levels. Although the results of this study can only show the benefits of compost additions during the first year after planting, the increased growth and the subsequent health of plants measured in this experiment resulting from applications of compost may prevent future plant failure. Future research should determine if improved plant growth in compostamended soils was a result of additions of $\mathrm{N}$ in the compost, enhanced mineralization of compost $\mathrm{N}$ resulting from increased soil microbial activity, or improved soil physical properties (specifically water-holding capacity). Future research should also evaluate the long-term effects of compost addition after the plant establishment period.

\section{Literature Cited}

Adeoye, K.B. and M.A. Mohamedsaleem. 1990. Comparison of effects of some tillage methods on soil physical-properties and yield of maize and stylo in a degraded ferruginous tropical soil. Soil Tillage Res. 18:63-72.

Akinci, I., E. Cakir, M. Topakci, M. Canakci, and O. Inan. 2004. The effect of subsoiling on soil resistance and cotton yield. Soil Tillage Res. 77:203-210.

Bishop, J.C. and D.W. Grimes. 1978. Precision tillage effects on potato root and tuber production. Amer. Potato J. 55:65-71.

Blake, G.R. and K.H. Hartge. 1986. Bulk density, p. 363-375. In: Campbell, G.S., R.D. Jackson, M.M. Mortland, D.R. Nielsen, and A. Klute (eds.). Methods of soil analysis, Part 1: Physical and mineralogical methods. Soil Science Society of America, Madison, WI.

Bouyoucos, G.J. 1962. Hydrometer method improved for making particle size analyses of soils. Agron. J. 54:464.

Bulmer, C., K. Venner, and C. Prescott. 2007. Forest soil rehabilitation with tillage and wood waste enhances seedling establishment but not height after 8 years. Can. J. For. Res. 37:1894-1906.

Busscher, W.J., J.M. Novak, P.G. Hunt, and P.J. Bauer. 2006. Increase of soil strength over time in a US southeastern coastal plain loamy sand. Soil Sci. 171:519-526.

Caravaca, F., D. Figueroa, M.M. Alguacil, and A. Roldan. 2003. Application of composted urban residue enhanced the performance of afforested shrub species in a degraded semiarid land. Bioresour. Technol. 90:65-70.

Casale, W.L., V. Minassian, J.A. Menge, C.J. Lovatt, E. Pond, E. Johnson, and F. Guillemet. 1995. Urban and agricultural wastes for use as mulches on avocado and citrus and for delivery of microbial biocontrol agents. J. Hort. Sci. 70: 315-332.

Cogger, C.G. 2005. Potential compost benefits for restoration of soils disturbed by urban development. Compost Sci. Util. 13:243-251.

Curtis, M.J. and V.P. Claassen. 2009. Regenerating topsoil functionality in four drastically disturbed soil types by compost incorporation. Restor. Ecol. 17:24-32.

da Silva, A.P., B.D. Kay, and E. Perfect. 1997. Management versus inherent soil properties effects on bulk density and relative compaction. Soil Tillage Res. 44:81-93.

Eghball, B. 1999. Liming effects of beef cattle manure or compost. Commun. Soil Sci. Plant Anal. 30:2563-2570.

Eghball, B. 2002. Soil properties as influenced by phosphorus- and nitrogen-based manure and compost applications. Agron. J. 94:128-135.

Ervin, E.H. and A.J. Koski. 2001. Kentucky Bluegrass growth response to trinexapac-ethyl, traffic, and nitrogen. Crop Sci. 41:1871-1877.

Foshee, W.G., III, W.D. Goff, M.G. Patterson, K.M. Tilt, W.A. Dozier, Jr., L.S. Tucker, and J.S. Bannon. 1999. Organic mulches affect soil and leaf nutrient levels of young pecan trees. Journal of Arboriculture 25:81-84.

Gilley, J.E. and B. Eghball. 2002. Residual effects of compost and fertilizer applications on nutrients in runoff. Trans. ASAE 45:1905-1910.

Gilman, E.F., M. Paz, and C. Harchick. 2010. Root ball shaving improves root systems on seven tree species in containers. J. Environ. Hort. 28 : $13-18$.
Ginting, D., A. Kessavalou, B. Eghball, and J.W. Doran. 2003. Greenhouse gas emissions and soil indicators four years after manure and compost applications. J. Environ. Qual. 32:23-32.

Gregory, J.H., M.D. Dukes, P.H. Jones, and G.L. Miller. 2006. Effect of urban soil compaction on infiltration rate. J. Soil Water Conserv. 61: $117-124$.

Hanks, D. and A. Lewandowski. 2003. Protecting urban soil quality: Examples for landscape codes and specifications. USDA-NRCS, Washington, DC. 7 Apr. 2010. <http://soils.usda.gov/sqi/ management/files/protect_urban_sq.pdf $>$.

Himelick, E.B. and G.W. Watson. 1990. Reduction of oak chlorosis with wood chip mulch treatments. Journal of Arboriculture 16:275-278.

Ingelmo, F., R. Canet, M.A. Ibanez, F. Pomares, and J. Garcia. 1998. Use of MSW compost, dried sewage sludge, and other wastes as partial substitutes for peat and soil. Bioresour. Technol. 63:123-129.

Jim, C.Y. 1993. Soil compaction as a constraint to tree growth in tropical \& subtropical urban habitats. Environ. Conserv. 20:35-49.

Jim, C.Y. 1998. Urban soil characteristics and limitations for landscape planting in Hong Kong. Landsc. Urban Plan. 40:235-249.

Johnson, G.A., J.G. Davis, Y.L. Qian, and K.C. Doesken. 2006. Topdressing turf with composted manure improves soil quality and protects water quality. Soil Sci. Soc. Amer. J. 70: 2114-2121.

Kaye, J.P., P.M. Groffman, N.B. Grimm, L.A. Baker, and R.V. Pouyat. 2006. A distinct urban biogeochemistry? Trends Ecol. Evol. 21:192199.

Kidder, G., E.A. Hanlon, T.H. Yeager, and G.L. Miller. 1998. IFAS standardized fertilization recommendations for environmental horticulture crops. University of Florida, IFAS, Gainesville, FL.

Knox, G.T., T. Broschat, and R. Black. 2002. Fertilizer recommendations for landscape plants. University of Florida-IFAS, Gainesville, FL. 21 Oct. 2009. <http://edis.ifas.ufl.edu/ EP114>.

Kozlowski, T.T. 1999. Soil compaction and growth of woody plants. Scand. J. For. Res. 14:596619.

Landschoot, P. and A. McNitt. 1994. Improving turf with compost. Biocycle 34:54-58.

Law, N., L. Band, and M. Grove. 2004. Nitrogen input from residential lawn care practices in suburban watersheds in Baltimore county, MD. J. Environ. Plann. Manage. 47:737-755.

Linde, D.T. and L.D. Hepner. 2005. Turfgrass seed and sod establishment on soil amended with biosolid compost. HortTechnology 15:577583.

Lipiec, J. and W. Stepniewski. 1995. Effects of soil compaction and tillage systems on uptake and losses of nutrients. Soil Tillage Res. 35:37-52.

Litvany, M. and M. Ozores-Hampton. 2002. Compost use in commercial citrus in Florida. HortTechnology 12:332-335.

Martens, D.A. and W.T. Frankenberger. 1992 Modification of infiltration rates in an organicamended irrigated soil. Agron. J. 84:707-717.

Miyamoto, S., I. Martinez, M. Padilla, A. Portillo, and D. Ornelas. 2004. Landscape plant lists for salt tolerance assessment. Texas A\&M University, El Paso, TX.

Murphy, J.A., P.E. Rieke, and A.E. Erickson. 1993. Core cultivation of a putting green with hollow and solid tines. Agron. J. 85:1-9.

Mylavarapu, R.S. 2009. UF/IFAS Extension soil testing laboratory (ESTL) analytical procedures and training manual. Circular 1248:19. 
Pandey, C. and S. Shukla. 2006. Effects of soil organic amendment on water and nutrient movement in a sandy soil, 2006 ASABE Annual International Meeting, Portland, OR.

Rivenshield, A. 2003. The effects of organic amendments on tree growth in compacted soils. PhD diss., Cornell University, Ithaca, NY.

Rivenshield, A. and N. Bassuk. 2007. Using organic amendments to decrease bulk density and increase macroporosity. Arboriculture \& Urban Forestry 33:140-146.

Roy, S., K. Arunachalam, B.K. Dutta, and A. Arunachalam. 2010. Effect of organic amendments of soil on growth and productivity of three common crops viz. Zea mays, Phaseolus vulgaris and Abelmoschus esculentus. Appl. Soil Ecol. 45:78-84.

Sartain, J.B. 2007. General recommendations for fertilization of turfgrasses on Florida soils. University of Florida-IFAS, Gainesville, FL. 21 Oct. 2009. <http://edis.ifas.ufl.edu/LH014>.

Sartain, J.B. 2008. Soil and tissue testing and interpretation for Florida turfgrasses. University of Florida/IFAS, Gainesville, FL. 19 May 2010. <http://edis.ifas.ufl.edu/ss317>

SAS Institute. 2003. SAS/STAT 9 and 9.1 users guide. SAS Institute, Cary, NC.

Scharenbroch, B.C. 2009. A meta-analysis of studies published in Arboriculture \& Urban Forestry relating to organic materials and impacts on soil, tree, and environmental properties. Arboriculture \& Urban Forestry 35:221-231.

Scheiber, S.M., E.F. Gilman, M. Paz, and K.A. Moore. 2007. Irrigation affects landscape establishment of Burford Holy, Pittosporum, and Sweet Viburnum. HortScience 42:344-348.

Smith, K.D., P.B. May, and G.M. Moore. 2001. The influence of compaction and soil strength on the establishment of four Australian landscape trees. Journal of Aboriculture 27:1-7.

Sommerfeldt, T.G. and C. Chang. 1985. Changes in soil properties under annual applications of feedlot manure and different tillage practices. Soil Sci. Soc. Amer. J. 49:983-987.

South Florida Water Management District. 2010. South Florida Water Management District yearround landscape irrigation rule. South Florida Water Management District, West Palm Beach, FL. 31 Aug. 2010. <http://www.sfwmd.gov/ portal/page/portal/xrepository/sfwmd_repository_ pdf/jtf_yr_rule_new.pdf $>$.

St. Johns River Water Management District. 2010 Watering restrictions. St. Johns Water Management District, Palatka, FL. 31 Aug. 2010. <http:// sjr.state.fl.us/wateringrestrictions/index.html $>$.

Stamatiadis, S., M. Werner, and M. Buchanan. 1999. Field assessment of soil quality as affected by compost and fertilizer application in a broccoli field (San Benito County, California). Appl. Soil Ecol. 12:217-225.

Tan, K.H. 1996. Measurement of field capacity water, p. 67-68. Soil sampling, preparation, and analysis. Marcel Dekker, New York, NY.

Thomas, G.W., G.R. Haszler, and R.L. Blevins 1996. The effects of organic matter and tillage on maximum compactability of soils using the proctor test. Soil Sci. 161:502-508.

Unger, P.W. and T.C. Kaspar. 1994. Soil compaction and root growth-A review. Agron. J. 86: 759-766.

Urban, J. 2008. Up by roots. International Society of Arboriculture, Champaign, IL.

USDA-NRCS. 2004. Official soil series descriptions. USDA-NRCS. 21 Oct. 2009. < http://soils usda.gov/soils/technical/classification/osd/index. html>.
Warman, P.R., J.C. Burnham, and L.J. Eaton. 2009. Effects of repeated applications of municipal solid waste compost and fertilizers to three lowbush blueberry fields. Sci. Hort. 122:393398.

Watson, G.W. and P. Kelsey. 2005. The impact of soil compaction on soil aeration and fine root density of Quercus palustris. Urban For. Urban Green. 4:69-74.

Weindorf, D.C., R.E. Zartman, and B.L. Allen. 2006. Effect of compost on soil properties in Dallas, Texas. Compost Sci. Util. 14:59-67.

Wickham, J.D., R.V. O’Neill, K.H. Riitters, E.R. Smith, T.G. Wade, and K.B. Jones. 2002. Geographic targeting of increases in nutrient export due to future urbanization. Ecol. Appl. 12:93-106.

Wright, A.L., T.L. Provin, F.M. Hons, D.A. Zuberer, and R.H. White. 2007. Compost source and rate effects on soil macronutrient availability under saint Augustine grass and Bermuda grass turf. Compost Sci. Util. 15:2228.

Yeager, T.H. 2010. Use of tissue analyses in woody ornamental nurseries. University of Florida/ IFAS, Gainesville, FL. 19 May 2010. <http:// edis.ifas.ufl.edu/cn001>.

Zazueta, F.S., A. Brockway, L. Landrum, and B. McCarty. 2005. Turf irrigation for the home. UF-IFAS, Gainesville, FL. 31 July 2009. <http:// edis.ifas.ufl.edu/AE144>.

Zhang, H. 1994. Organic matter incorporation affects mechanical properties of soil aggregates. Soil Tillage Res. 31:263-275.

Zhang, S., H. Grip, and L. Lovdahl. 2005. Effect of soil compaction on hydraulic properties of two loess soils in China. Soil Tillage Res. 90:117125 . 